\title{
Mucin Release from Rabbit Tracheal Epithelium in Response to Sera from Normal and Cystic Fibrosis Subjects
}

\author{
THOMAS F. BOAT, ${ }^{(21)}$ ILONA POLONY, AND PI WAN CHENG \\ Cystic Fibrosis Center, Department of Pediatrics, Case Western Reserve University School of Medicine and Rainbow \\ Babies and Childrens Hospital, Cleveland, Ohio, USA
}

\begin{abstract}
Summary
We have developed an assay for the release of mucous glycoproteins secreted by rabbit tracheal mucosa to study the mucusstimulating properties of cystic fibrosis (CF) serum. Glycoproteins are labeled to equilibrium with both $\left.\left.\right|^{35}\right]$-sulfate and $\left[{ }^{3} \mathrm{H}\right]$-glucosamine. The relative secretory rate (RSR) of these glycoproteins is assessed after incubation with $\mathbf{5 0 \%}(\mathrm{v} / \mathrm{v}) \mathrm{CF}$ and control sera. Serum from all sources significantly increased the RSR for incubation times ranging from $10 \mathrm{~min}$ to $4 \mathrm{~h}$. CF serum produced a significantly greater RSR than control serum after 10 min exposure, but not after longer exposure intervals. After $10 \mathrm{~min}, \mathbf{R S R}$ for $\left[{ }^{35} \mathrm{SO}_{4}\right]$-glycoproteins was $3.6 \pm 0.2$ in the presence of sera from healthy individuals, and $2.3 \pm 0.4$ in the presence of sera from control patients with lung disease. Heterozygote RSR values were usually higher than control values, but not different than $C F$ homozygote values. The $\mathrm{CF}$ serum activity was reduced by freezing and thawing. Increasing the calcium content of incubation medium did not alter serum effects. Calcium inophore A23187 did not mimic CF serum activity. High molecular weight and albumin, but not IgG, fractions from Sephadex G-200 chromatography of CF and control sera generally contained high levels of mucin-release activity. No chromatographic pattern of activity was distinctive for CF.
\end{abstract}

\section{Speculation}

Serum contains multiple substances, which promote the release of mucins from airways surface epithelium. Cystic fibrosis serum contains additional mucin-release activity, which does not appear to reside in a single serum component. This activity may be related to hypersecretion of mucus in people with cystic fibrosis.

Exposure of mucus-secreting epithelia to serum promotes the release of mucus in a number of experimental systems. Serum from people with cystic fibrosis (CF) reportedly produces an exaggerated secretory response. Bowman and associates $(2,8)$ observed increased release of mucus as well as inhibition of ciliary activity on exposure of oyster gills to CF serum. Bogart and coworkers (6) noted a similar response of rabbit tracheal epithelium, which was exposed to $\mathrm{CF}$ serum. In both studies this effect was observed microscopically, but never quantitated. Czegledy-Nagy and Sturgess (12) reported swelling of goblet cells in rabbit tracheal epithelium followed by release of their contents at an earlier point in time in the presence of $\mathrm{CF}$ as compared with control sera. Subsequently, Conover and Conod (11) reported an increased release of sedimentable, sialic acid-containing material from rabbit tracheal epithelium exposed to CF sera. The nature of this material was not determined, but was presumed to be mucus. More recently, Fleming and Sturgess (14) noted increased release of macromolecules labeled with $\left[{ }^{14} \mathrm{C}\right]$-glucosamine from isolated rat submandibular gland cells exposed to CF serum. This effect also was seen with serum of patients with other pulmonary diseases. Finally, Kurlansky and co-workers (16) have reported greater elongation of the mucous tail extruded by urn cells of the sea worm, Sipunculus nudus, in the presence of heat-treated CF and CF heterozygote, as compared with control sera. This activity appears to be noncovalently bound to $\mathrm{IgG}$.

These observations are of potential importance, as they may relate to abnormalities of mucus clearance, a prominent pathogenetic factor in CF; however, most of these studies have employed subjective or semiquantitative end points and none have specifically identified mucous glycoprotein (mucin) as a material released in response to CF serum. We have developed a system for quantitating mucous glycoprotein (mucin) release from rabbit tracheal epithelium and have employed this system to reexamine the putative mucus-releasing effect of CF serum.

\section{PATIENTS AND METHODS}

Blood donors for this study were (1) $\mathrm{CF}$ patients receiving care at the Cleveland CF Center (ages 8-35), (2) parents of CF patients (ages 21-42) and (3) age-and sex-matched normal volunteers. In addition, sera from symptomatic patients (ages 10-19) with asthma or asthmatic bronchitis, but taking no medications, were tested. All CF patients had sweat chloride concentrations greater than 70 meq/liter and typical respiratory and/or gastrointestinal manifestations of this disease. They were not acutely ill, did not have severe chronic obstructive lung disease, and were taking no medications with the exception of pancreatic enzymes and supplementary vitamins. Clinical scores (13) of these patients ranged from 65-93 (mean, 82). None of the parents or normal volunteers had a known medical disorder or was taking medications. Both sexes were equally represented in each group of subjects.

Blood specimens were drawn into plastic syringes, transferred into glass tubes, clotted and centrifuged at $4^{\circ} \mathrm{C}$. Sera often did not clot completely if processed entirely in plastic containers and subsequently formed clots when added to culture dishes containing tissue explants. Separated serum was stored in plastic containers either at $4^{\circ} \mathrm{C}$ for periods of time up to $4 \mathrm{~h}$ before testing or frozen at $-70^{\circ} \mathrm{C}$ until assayed for mucus-stimulating properties in selected experiments.

Tracheas were removed from pentobarbitol anesthetized rabbits and placed in chilled Hanks balanced salt solution. Each trachea was opened longitudinally along the membranous portion and pinned flat. The mucosa and upper submucosa were dissected from underlying cartilages and cut into 2 or $3 \mathrm{~mm}^{2}$ explants, which were randomly assigned to 3 or 4 different Falcon petri dishes each containing $2 \mathrm{ml}$ of medium 199 (Gibco) with Earles salts, $100 \mu \mathrm{g} / \mathrm{ml}$ of carbenicillin, $1.0 \mu \mathrm{g} / \mathrm{ml}$ of amphoteracin, and the labeled glycoprotein precursors, $\left[{ }^{35} \mathrm{SO}_{4}\right]$ and $\left[6-{ }^{3} \mathrm{H}\right]$-D-glucosamine. Explants were cultured for $24 \mathrm{~h}$ at $35^{\circ} \mathrm{C}$ in a water-saturated environment containing $40 \%$ oxygen and $5 \%$ carbon dioxide. 
At the end of this $24-\mathrm{h}$ period $\left(\mathrm{P}_{1}\right)$ explant surfaces were gently irrigated to dislodge secreted mucus and the culture medium was removed. Explants were washed twice with an additional $2 \mathrm{ml}$ of unlabeled culture medium and the washings combined with the original medium for analysis of labeled macromolecules. To the 3 dishes were added either (1) unlabeled medium 199, (2) unlabeled medium 199 containing 50\% control serum, (3) unlabeled medium 199 containing 50\% CF serum and, in some cases, (4) unlabeled medium 199 containing 50\% serum from obligate CF heterozygotes or from asthma patients. Explants were reincubated in these media for periods of time ranging from $10 \mathrm{~min}$ to $4 \mathrm{~h}\left(\mathrm{P}_{2}\right)$. Media were removed, again with gentle irrigation of the explant surface, and analyzed for content of labeled macromolecules.

For experiments using fractionated serum, blood was clotted, and $3 \mathrm{ml}$ of serum was immediately applied to a $1.5 \times 50 \mathrm{~cm}$ column of Sephadex G-200. The column was eluted at $4^{\circ} \mathrm{C}$ with phosphate buffered saline $(\mathrm{pH} \mathrm{7.4)}$ and $1.5 \mathrm{ml}$ fractions were collected. Elution rates were approximately $25 \mathrm{ml}$ per h. Fractions were tested immediately in the rabbit tracheal explant system, along with $50 \%$ serum from the same donor. A 10 -min exposure period was used. A single modification was introduced for assay of serum fractions; explants were placed in smaller petri dishes so that only $1.0 \mathrm{ml}$ of test medium was required.

All harvested media were solubilized by addition of dithiothreitol to a final concentration of $5 \mathrm{mM}$, and aliquots were precipitated by adding an equal volume of a solution containing $10 \%$ trichloroacetic acid (TCA) and 2\% phosphotungstic acid (PTA). Precipitates were collected by centrifugation, suspended and washed 3 times with 5\% TCA, 1\% PTA, and resolubilized with $10 \% \mathrm{H}_{2} \mathrm{O}_{2}$ and $66 \%$ hydroxide of hyamine (1). Solubilized precipitates were counted by double isotope techniques as previously utilized in studies of human tracheal secretions (3).

Secretory rates for radiolabeled macromolecules were determined (counts/unit time/g tissue) and a relative secretory rate (RSR) for explants exposed to serum in each experiment was calculated using the formula:

$$
\mathrm{RSR}=\frac{\mathrm{P}_{2} \text { secretory rate }(\text { with serum }) / \mathrm{P}_{1} \text { secretory rate }}{\mathrm{P}_{2} \text { secretory rate }(\text { no serum }) / \mathrm{P}_{1} \text { secretory rate }}
$$

Differences between RSR values and 1 were analyzed by a 1 sample $t$ test with an expected value of 1 in the numerator (10) and differences between mean RSR's of various experimental conditions were analyzed using the paired $t$ test.

Other procedures. Protein was assayed by the Lowry method, using bovine serum albumin as standard (17). Analyses of fucose, galactose, glucosamine, galactosamine, and sialic acid were carried out by gas liquid chromatography of the trimethylsilyl derivatives as previously described (4). Blood group B substance was determined by hemagglutination-inhibition assay. BioGel A-5 m chromatography of reduced and carboxymethylated rabbit tracheal secretions, was carried out as previously described (4). The high molecular weight mucous glycoprotein fraction was treated with 200 units of pig testicular hyaluronidase (Worthington) in $3 \mathrm{ml}$ of $0.1 \mathrm{M}$ phosphate buffer, $\mathrm{pH}$ 5.3. The reaction was carried out in a dialysis bag in the presence of a 100 -fold volume of dialysis fluid (same buffer) at $37^{\circ} \mathrm{C}$ for $24 \mathrm{~h}$. Dialyzable and nondialyzable tritium and $\left[{ }^{35} \mathrm{SO}_{4}\right]$ counts were assayed after enzyme treatment.

\section{RESULTS}

Labeling of secreted glycoproteins. Rabbit tracheal epithelium was incubated in medium containing $\left[{ }^{35} \mathrm{SO}_{4}\right]$ and $\left[6-{ }^{3} \mathrm{H}\right]$-D-glucosamine; the medium was harvested and analyzed at $24-\mathrm{h}$ intervals for content of protein, glycoprotein (nondialyzable carbohydrate) and labeled macromolecules. Figure 1 shows that relatively large amounts of protein were released into medium during the first 24 $\mathrm{h}$ in culture. Thereafter, protein was secreted at a constant rate, 7$9 \mathrm{mg} / \mathrm{g}$ tissue $/ 24 \mathrm{~h}$. In contrast, the rate of release of macromolecular carbohydrate was relatively constant throughout the $96-\mathrm{h}$ culture period (3-5 $\mu$ mole $(0.6-1.0 \mathrm{mg}) / \mathrm{g}$ tissue $/ 24 \mathrm{~h}$ ), suggesting a steady state rate for mucous glycoprotein secretion. Equilibrium

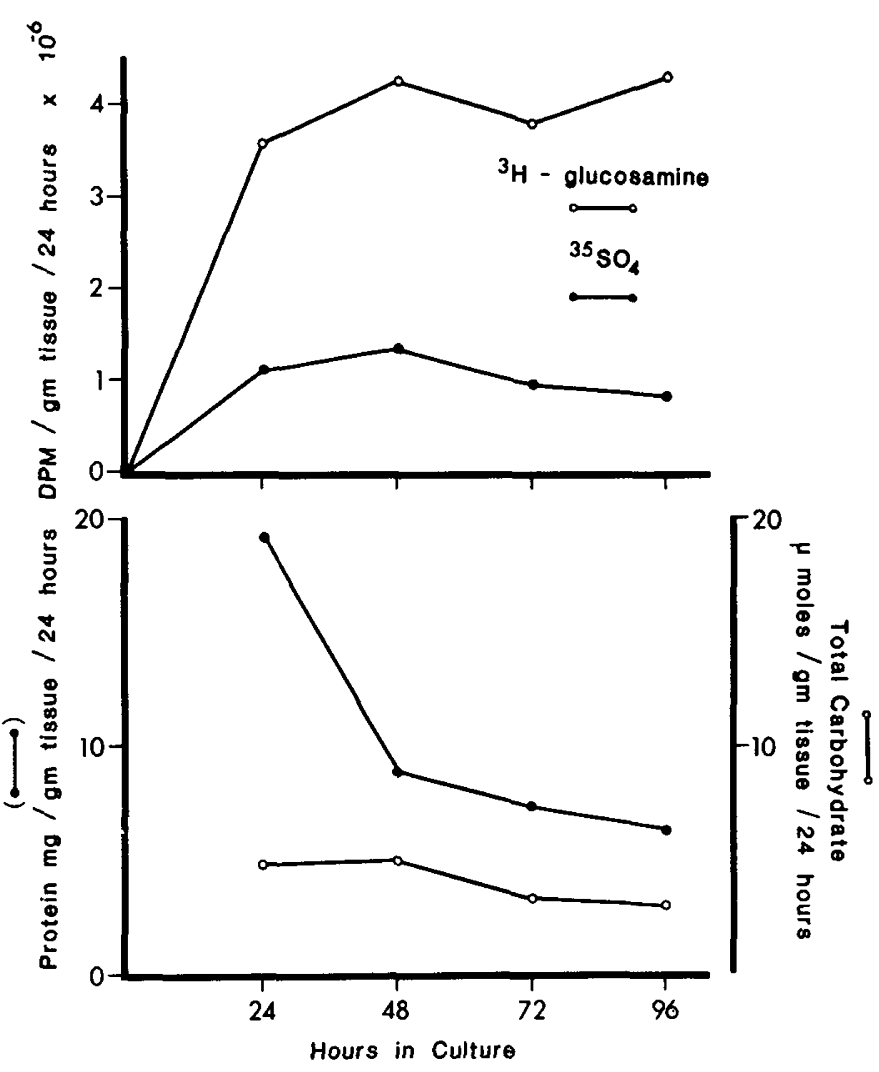

Fig. 1. Serial analyses of secretory rates for protein, glycoprotein carbohydrate, and labeled macromolecules from explanted rabbit tracheal epithelium. Medium was harvested after each 24 -h culture period, dialyzed exhaustively against water; lyophilized and reconstituted with a known volume of water. Total carbohydrate was calculated as the sum of the 5 sugars present in mucous glycoproteins.

labeling of secreted macromolecules was achieved within the first $12 \mathrm{~h}$ after initiation of culture.

Characterization of labeled macromolecules. Reduced and carboxymethylated secretions from rabbit tracheal explants, incubated with bovine testicular hyaluronidase at $37^{\circ} \mathrm{C}$ for $24 \mathrm{~h}$, released less than $5 \%$ of macromolecular $\left[{ }^{35} \mathrm{SO}_{4}\right]$ and tritium as dialyzable counts, indicating minimal content of hyaluronic acid or chondroitin sulfate in culture medium. BioGel A-5m chromatography of explant secretions produced a peak at the void volume of the column, which contained $82 \%$ of the macromolecular tritium and $72 \%$ of macromolecular $\left[{ }^{35} \mathrm{SO}_{4}\right]$ (Fig. 2). Material in the void volume peak was characterized chemically. This material contained high titers of blood group B substance, had a high carbohydrate content $(>50 \%)$ and contained the five sugars typically found in mucous glycoproteins (Table 1). Mannose and uronic acid were not detectable in these fractions. Results of hyaluronidase treatment and gel filtration chromatography, together with chemical analyses, indicate that most of the $\left[{ }^{35} \mathrm{SO}_{4}\right]$ and tritium is incorporated by rabbit tracheal epithelium into high molecular weight mucous glycoproteins and that release of acid-precipitable $\left[{ }^{35} \mathrm{SO}_{4}\right]$ and tritium is a useful index of glycoprotein secretion.

Secretory responses of explants to serum. RSR values for labeled acid-precipitable glycoproteins generally ranged from 1.5-5.5 after exposure of explants to serum from both $\mathrm{CF}$ and control donors. The RSR values for control and CF serum were both significantly greater than $1(P<0.001)$ indicating an increase from baseline secretory rates. Elevated RSRs were observed for exposure periods ranging from $10 \mathrm{~min}$ to $4 \mathrm{~h}$. Serum was tested undiluted, and diluted in culture medium at $50 \%$ and $15 \%(\mathrm{v} / \mathrm{v})$ concentrations. Maximum RSRs were achieved with $50 \%$ serum, the concentration used for all subsequent comparisons of CF and control sera.

$\mathrm{CF}$ and control samples differed in their effects on mucous secretion only at the 10-min exposure period. Mean RSRs of 


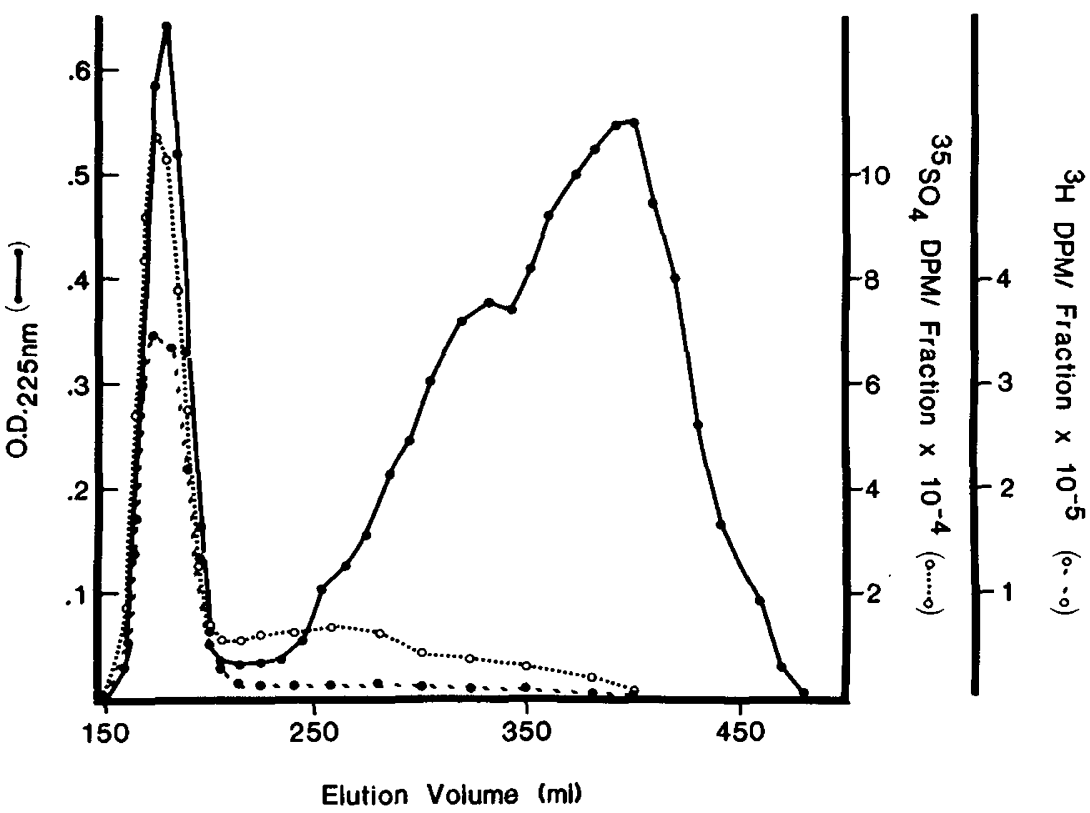

Fig. 2. Fractionation on BioGel A-5m of reduced and carboxymethylated secretions from rabbit tracheal epithelial explants. Column: $2.5 \times 80 \mathrm{~cm}$; $100 \mathrm{mM} \mathrm{NaCl}, 10 \mathrm{mM}$ Tris- $\mathrm{HCl}(\mathrm{pH} 7.0)$ eluant. Greater than $90 \%$ of $\left[{ }^{35} \mathrm{SO}_{4}\right]-$ and $\left[{ }^{3} \mathrm{H}\right]$-counts applied to the column were recovered in the fractions.

Table 1. Carbohydrate composition of material from rabbit tracheal secretions in the void volume fraction after BioGel A-5m chromatography

\begin{tabular}{lcc}
\hline & $\mu$ mole/fraction & moles/mole galactosamine \\
\hline Fucose & 0.224 & 1.2 \\
Galactose & 0.725 & 3.9 \\
Galactosamine & 0.186 & 1.0 \\
Glucosamine & 0.365 & 2.0 \\
Sialic acid & 0.084 & 0.5 \\
\hline
\end{tabular}

$\left[{ }^{35} \mathrm{SO}_{4}\right]$ and tritium-labeled glycoprotens were higher for $\mathrm{CF}$ (3.6 for $\left.{ }^{35} \mathrm{SO}_{4}\right] ; 2.8$ for $\left.\left[{ }^{3} \mathrm{H}\right]\right)$ than for control $\left(2.4\right.$ for $\left[{ }^{35} \mathrm{SO}_{4}\right] ; 2.1$ for $\left.\left[{ }^{3} \mathrm{H}\right]\right)$ sera after this short interval (Fig. 3). Although overlap of values was extensive, RSRs for $\left[{ }^{3} \mathrm{H}\right]$-glycoproteins and $\left[{ }^{35} \mathrm{SO}_{4}\right]-$ glycoproteins in the presence of CF sera exceeded those in the presence of control sera in 16 of 18 and 15 of 18 paired experiments respectively. Analysis of paired responses showed that CF sera effected significantly greater responses than control sera $(P<$ $0.01)$. CF serum samples frozen at $-70^{\circ} \mathrm{C}$ for $2-100$ days did not consistently increase RSR values above those of control sera. Mean RSR values were virtually identical for fresh or frozen control sera.

In a separate set of experiments using a 10-min incubation period, RSR values for oligate CF heterozygotes tended to be slightly higher than those for healthy controls (mean, 3.8 versus 3.1 for $\left[{ }^{35} \mathrm{SO}_{4}\right]$-glycoproteins; 2.9 versus 2.15 for $\left[{ }^{3} \mathrm{H}\right]$-glycoproteins) and essentially the same as for CF subjects (Fig. 4). Extensive overlap of values from the three groups was encountered. RSR values for heterozygote sera were higher than those for control sera in six and seven of nine paired experiments for $\left[{ }^{3} \mathrm{H}\right]$-glycoproteins and $\left[{ }^{35} \mathrm{SO}_{4}\right]$-glycoproteins respectively.

Mean responses ( \pm S.E.) for six serum samples from patients with other chronic lung conditions were $2.0 \pm 0.2$ and $2.3 \pm 0.4$ for $\left[{ }^{35} \mathrm{SO}_{4}\right]$ - and $\left[{ }^{3} \mathrm{H}\right]$-labeled macromolecules, respectively, not different than control, but significantly different than $C F$ responses $(P<0.05)$.

Increasing the calcium content of culture medium so that the final mixture with serum was $5.5 \mathrm{mM}$ instead of $3 \mathrm{mM}$ with respect to divalent cation did not enhance differences between the RSRs produced by CF and control sera (Table 2). Similarly, addition of $10^{-4} \mathrm{M}$ calcium ionophore (A23187, Lilly) to control

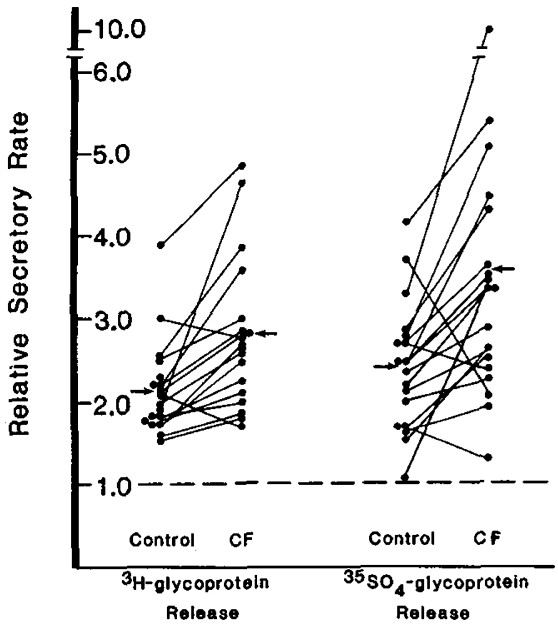

Fig. 3. Relative secretory rate values for $\left[{ }^{3} \mathrm{H}\right]-$ and $\left[{ }^{35} \mathrm{SO}_{4}\right]$-labeled glycoproteins in response to $\mathrm{CF}$ and control sera. Paired data were generated from serum samples assayed simultaneously using tracheal explants from the same rabbit. Arrows indicate means for each set of relative secretory rate values. Serum exposure time was $10 \mathrm{~min}$.

serum in the presence of $3 \mathrm{mM}$ or $5.5 \mathrm{mM}$ calcium did not increase or decrease RSR values (Table 2). Use of citrated plasma in three experiments decreased the RSR of both CF and control sera (data not presented).

Exposure of explants for $\mathrm{t} h$ to $50 \%$ serum from all donors (CF, control) also promoted the release of labeled glycoproteins (Fig. 5); however, at this longer exposure interval RSR values for all sera were generally diminished and CF serum had no more effect on glycoprotein release than did control serum. Similar results were obtained when $\mathrm{CF}$ and control sera were incubated with tracheal epithelium for $4 \mathrm{~h}$.

Sephadex G-200 fractionation of serum from all sources yielded 3 major protein peaks (Fig. 6). Fractions from each of these peaks, fractions eluted between the major peaks and fractions eluted with and just after lysozyme (containing low molecular weight components) were assayed for mucin-release effects. RSR values (10min exposure) for fractions from four CF and three control serum samples failed to fall into obvious patterns (Table 3). For six of 


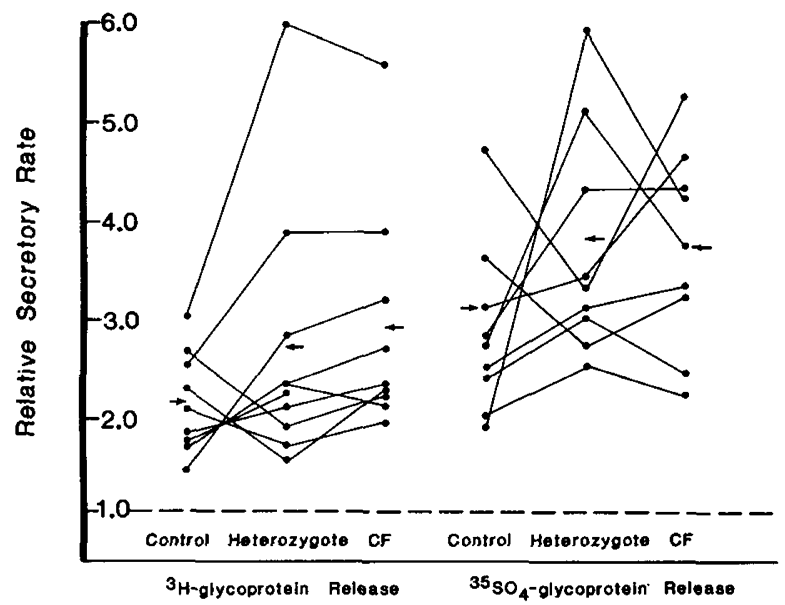

Fig. 4. Relative secretory rate values for $\left[{ }^{3} \mathrm{H}\right]-$ and $\left[{ }^{35} \mathrm{SO}_{4}\right]$-labeled glycoproteins in response to $\mathrm{CF}$, oligate heterozygote, and control sera. Paired data were generated independently of those presented in Figure 4. Serum exposure time was $10 \mathrm{~min}$

Table 2. Effect of calcium on relative secretory rate (RSR) values RSR

\begin{tabular}{llccc}
$\begin{array}{c}\text { Serum } \\
\text { source }\end{array}$ & $\begin{array}{c}\text { Medium } \\
\text { composition }\end{array}$ & $\mathrm{n}$ & $\begin{array}{c}\left.{ }^{35} \mathrm{~S}\right] \text { glycopro- } \\
\text { teins }\end{array}$ & $\begin{array}{c}{\left[{ }^{3} \mathrm{H}\right] \text { glycopro- }} \\
\text { teins }\end{array}$ \\
\hline Control & $3.0 \mathrm{mM} \mathrm{Ca}^{+2}$ & 5 & $2.6 \pm 0.5$ & $2.1 \pm 0.4$ \\
Control & $5.5 \mathrm{mM} \mathrm{Ca}^{+2}$ & 4 & $2.5 \pm 0.4$ & $2.2 \pm 0.3$ \\
Control & $5.5 \mathrm{mM} \mathrm{Ca}^{+2}$ & 5 & $2.5 \pm 0.3$ & $2.1 \pm 0.4$ \\
& $+\mathrm{A}^{2} 3187$ & & & \\
$\mathrm{CF}$ & $3.0 \mathrm{mM} \mathrm{Ca}^{+2}$ & 5 & $3.2 \pm 0.6$ & $2.6 \pm 0.5$ \\
$\mathrm{CF}$ & $5.5 \mathrm{mM} \mathrm{Ca}^{+2}$ & 4 & $3.1 \pm 0.4$ & $2.7 \pm 0.6$ \\
\hline
\end{tabular}

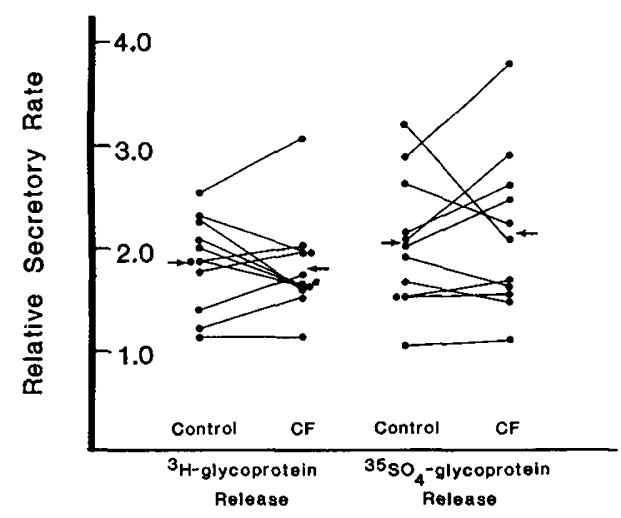

Fig. 5. Relative secretory rate values for $\left[{ }^{3} \mathrm{H}\right]-$ and $\left[{ }^{35} \mathrm{SO}_{4}\right]$-labeled glycoproteins in response to $\mathrm{CF}$ and control sera. Serum exposure time was $60 \mathrm{~min}$.

seven serum samples (two CF, three control), none of the fractions tested gave an RSR greater than that of $50 \%$ unfractionated serum. The highest RSR was generated by peak I fractions from three sera (two control), and by peak III fractions in the three other sera (two CF). Peak II fractions, which contain serum IgG, produced the highest RSR in only one experiment and the lowest RSR value in four of the other six experiments. RSR values for fractions containing low molecular weight components were not different than one. Fractions from trough areas had variable effects on glycoprotein secretion. For example, although Figure 6A shows a high RSR (4.2) for the fraction eluting between peaks II and III, the same fraction from another CF serum showed little stimulation of secretions $(\mathrm{RSR}=2.1)$. When $\mathrm{RSR}$ values were standardized on the basis of protein content of each fraction, the highest values were invariably associated with peak I material; however, the

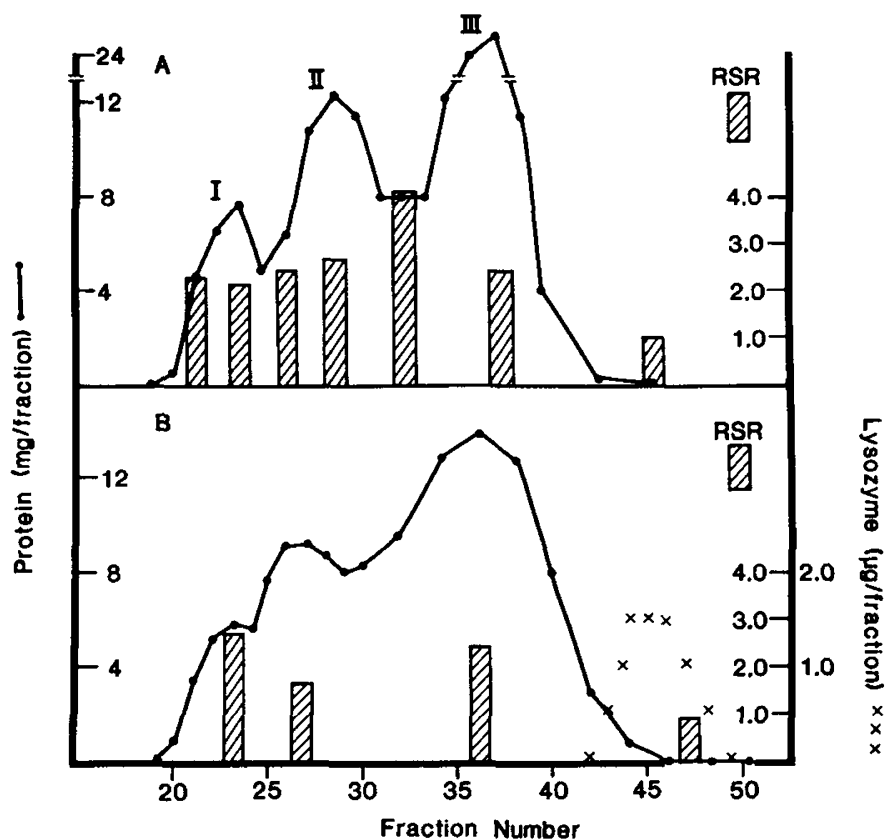

Fig. 6. Relative secretory rate values for fractions from sera of two subjects with CF. Serum was rapidly fractionated on Sephadex G-200. Aliquots of selected fractions were immediately assayed for release of glycoprotein, along with a 50\% dilution of unfractionated serum. Relative secretory rate for unfractionated serum in $6 \mathrm{~A}$ was 4.4 , and in $6 \mathrm{~B}$ was 2.7 . Fraction volumes were $1.5 \mathrm{ml}$. Fractions were assayed for protein by the method of Lowry, and lysozyme activity was determined by the lysoplate method of Osserman and Lawlor (18).

Table 3. Relative secretory rate values for serum fractions ${ }^{1}$

\begin{tabular}{lccccc}
\hline Serum & & & & Small & $50 \%$ \\
source & Peak I & Peak II & Peak III & MW & $\begin{array}{c}\text { Serum } \\
\text { Control-1 }\end{array}$ \\
& 1.6 & 1.8 & 2.5 & 0.8 & 2.6 \\
Control-2 & $(0.7)$ & $(0.4)$ & $(0.1)$ & & \\
& 1.8 & 1.3 & 1.2 & & 1.8 \\
Control-3 & $(0.6)$ & $(0.3)$ & $(0.1)$ & & \\
& 1.4 & 1.0 & 1.2 & 0.4 & 2.2 \\
CF-1 & $(0.1)$ & $(0.1)$ & $(0.1)$ & & \\
& 2.7 & 1.6 & 2.4 & 0.9 & 2.7 \\
CF-2 & $(1.2)$ & $(0.2)$ & $(0.2)$ & & \\
& 1.2 & 1.4 & 2.2 & 0.9 & 2.2 \\
CF-3 & $(0.4)$ & $(0.2)$ & $(0.1)$ & & \\
& 2.1 & 2.1 & 3.5 & & 3.2 \\
CF-4 & $(0.7)$ & $(0.2)$ & $(0.2)$ & & \\
& 2.1 & 2.7 & 2.4 & & 4.4 \\
& $(0.5)$ & $(0.4)$ & $(0.1)$ & & \\
\hline
\end{tabular}

${ }^{1}$ Values in parenthesis are relative secretory rate/mg protein in fraction.

standardized RSR for the various fractions also did not differentiate $\mathrm{CF}$ and control sera.

\section{DISCUSSION}

Our data demonstrate that human serum from a variety of donors promotes the release of mucous glycoproteins from goblet cells of rabbit tracheal epithelium. Furthermore, fresh serum from relatively healthy subjects with $\mathrm{CF}$ is usually a more potent stimulator of mucus secretion than age- and sex-matched control sera. These results extend previous observations $(2,6,8,11,12$, $14,16)$ by demonstrating quantitatively that $\mathrm{CF}$ serum augments the release of substances, most likely mucous glycoproteins, from cells of mammalian airways.

We feel that the rabbit tracheal mucin-release assay, as employed in our studies, has several advantages. This assay measures 
a specific secretory event, release of prelabeled glycoproteins from intracellular stores. Perhaps most importantly it has a quantitative endpoint, which is lacking in most previous studies of CF serum effects on the secretion of mucus. Kurlandsky et al. (16) were able to quantitate the length of the mucus-tail of the urn cell in response to $\mathrm{CF}$ and other sera; however, a direct correlation between tail length and actual amount of glycoprotein secreted has not been established for their system. Fleming et al. (14) quantitated release of tritiated macromolecules from isolated rat submandibular cells in the presence of CF and control sera. A problem with interpretation of data from that and other studies that follow release of labeled macromolecules is uncertainty as to which secreted macromolecules are labeled. We have demonstrated that both tritium and sulfate labels are largely incorporated into typical high molecular weight mucous glycoproteins by rabbit tracheal epithelium. The absence of mannose rules out significant contribution to the high molecular weight fraction by serum-type glycoproteins such as immunoglobulins, which are secreted by plasma cells of the tracheal submucosa. Contribution of labeled proteoglycans from connective tissue elements has been ruled out by resistance of the secretory product to hyaluronidase and the absence of uronic acids. We were especially concerned about contamination with proteoglycans because Gallagher and Kent (15) reported the secretion of chondroitin sulfate and hyaluronic acid by rabbit tracheal explants; however, their explants differed from ours in that they contained cartilage, a rich source of these complex polysaccharides.

Another potential problem with the quantitation of glycoprotein secretion by labeling techniques is nonhomogeneous labeling of the secretory product. We achieved equilibrium labeling of secreted glycoproteins well within the first $24 \mathrm{~h}$ of culture, as documented by the release of glycoproteins labeled to a constant specific activity. Therefore, our labeling technique provides a quantitative assessment of total mucous glycoprotein secretion in response to serum. We expect that $\left[{ }^{3} \mathrm{H}\right]$-glucosamine and $\left[{ }^{35} \mathrm{SO}_{4}\right]$ colabel most if not all of the mucous glycoprotein molecules secreted by rabbit tracheal epithelium. Small differences in the release of macromolecular $\left[{ }^{35} \mathrm{~S}\right]$-sulfate and tritium in response to serum may reflect microheterogeneity of these glycoproteins with respect to sulfate content (4). Indeed, we have reported experiments elsewhere (5) that suggest that CF serum processed entirely in plastic, but not glass, containers promotes the release from rabbit tracheal epithelium of glycoproteins with a high $\left[{ }^{35} \mathrm{SO}_{4}\right] /$ tritium ratio.

The relationship of the mucin-secretion response seen in our system to the response of rabbit tracheal epithelium described by Conover and Conod (11) is unclear. Major methodologic differences exist between the two studies. Conover measured the dry weight or sialic acid content of material pelleting from undiluted serum which bathed rabbit epithelium for $1-24 \mathrm{~h}$ periods. Differences between $\mathrm{CF}$ and control sera were found at all time intervals, in contrast to our observation that differential CF effects on release of mucins are short-lived. Pelleted material was not identified by Conover as mucous glycoprotein. This material may have been, in part, cell membranes which are known to contain sialic acid, and which would reflect epithelial cell disruption in the presence of undiluted serum. Evidence has been presented for extensive injury to rabbit tracheal epithelium after exposure to undiluted serum for $15 \mathrm{~min}(7)$. Light and electron microscopic examination of epithelium exposed for $15 \mathrm{~min}$ to $50 \%$ human serum demonstrates intact ciliated and goblet cells (unpublished observation). We also were not able to confirm the observation that calcium iontophore A23187 mimics the CF serum effect on mucus secretion by rabbit tracheal epithelium (6). Our observations concerning the time course of the secretory effect of $\mathrm{CF}$ serum are generally in keeping with the morphologic observations of Czegledy-Nagy and Sturgess (12) who demonstrated swelling of goblet cells followed by discharge of their contents within $10-$ $20 \mathrm{~min}$ after exposure to $\mathrm{CF}$ serum.

A relationship between mucus-secretion and ciliary dyskinesia factors in CF serum has been proposed (9). Correlation between the two effects was not noted in our system. For example, rabbit explants exposed to both control and CF serum at a $50 \%$ concentration for $10 \mathrm{~min}$ demonstrated brisk ciliary activity and were able to transport carbon particles across their surface (unpublished observation); however, we have not systematically studied ciliary function of rabbit trachea in relationship to CF serum exposure or mucus-secretion.

CF patients were taking no medications except for vitamins and pancreatic enzymes. These restrictions were placed on selection of donors to minimize the possibility that factors secondary to the basic pathophysiology of CF might contribute to the mucin-release effect. On the other hand, we have not obtained definitive evidence that the mucus-secretion effect is directly related to the genetic abnormality in CF. Although the numbers of observations are relatively small, preliminary data on the effect of sera from $C F$ heterozygotes suggests that the mucin-release effect is not a purely secondary phenomenon. This conclusion is supported by our data which suggest no increased effect of sera from six patients with other chronic lung diseases.

The molecular basis for the mucus-stimulating activity in serum in general, or in CF serum specifically, has only recently received attention. Kurlandsky et al. (16) found that activity of heat-treated CF serum, as assessed by the urn cell assay, was bound by protein A-Sepharose, indicating an association with $\mathrm{IgG}$, but that it could be dissociated from IgG by $8 \mathrm{M}$ urea. In contrast, the results of our fractionation of serum, which was not heat treated, militate against a consistent contribution from IgG or IgG-associated substances to the mucin-release effect of CF serum, or for that matter, of serum from any source. Our data suggest that there are multiple macromolecular substances in human serum which trigger the release of goblet cell mucins from rabbit trachea and that the active serum components vary, at least quantitatively, from one individual to the next, whether $\mathrm{CF}$ or control. We found no evidence that the mucin-release activity in CF serum is qualitatively different from that in control subjects. The relationship of this activity to previously described CF-related mucus-stimulating activities $(2,6,8,11,12,14,16)$ should be explored.

Our current assay clearly is not useful for diagnostic purposes or genetic counceling. The fact that it measures release of mucin from goblet cells in mammalian airways is an attractive feature in that this assay ultimately may be useful to identify substances responsible for mucus hypersecretion in lungs of people with CF; however, we emphasize that there is as yet no evidence that activity in our assay is responsible for mucus hypersecretion in CF lungs.

If the mucin-release assay is to be a widely useful laboratory tool, further developmental work will be required. Lability of activity is a problem that requires further attention. In addition, the small differences between mucin-release activities of $\mathrm{CF}$ and control sera preclude consistent discrimination of CF-related effects. Our attempts to modify the mucin-release assay and improve discrimination between $\mathrm{CF}$ and control sera, including variation of serum concentration, variation of the duration of exposure, increasing the calcium content of culture medium, and use of serum fractions, have not been successful. Other manipulations such as heating serum to $85^{\circ} \mathrm{C} \mathrm{(16)} \mathrm{should} \mathrm{be} \mathrm{investigated;} \mathrm{how-}$ ever, we have purposely limited our variation of the assay conditions to those steps which are physiologic, in the hope that the activity measured can be related more easily to pathophysiologic events in CF.

\section{CONCLUSION}

We and others have provided evidence, both subjective and objective, for greater activity of circulating mucus-stimulating substances in CF than in control individuals. However, our investigations suggest that this activity as assayed by rabbit tracheal explants has multiple macromolecular determinants, acting independently or in an interdependent fashion. In addition, the various assays used to detect mucous stimulating substánces do not seem to measure the same activities. Identification of factors which 
effect the release of mucus, and determination of their relationship to the pathophysiology of CF appear to be worthwhile objectives. However, achievement of these objectives first may require an understanding of the mechanism(s) by which components of serum from healthy subjects trigger the release of mucins from respiratory epithelium.

\section{REFERENCES AND NOTES}

I. Baker, A. P., Hillegass, L. M., Holden, D. A., and Smith, W. J.: Effect of kallidin, substance $\mathrm{P}$, and other basic polypeptides on the production of respiratory macromolecules. Am. Rev. Resp. Dis., 115: 811 (1977).

2. Baur, P. S., Brinkley, B. R., and Bowman, B. H.: Effects of cystic fibrosis serum ciliary inhibitor on oyster gill ultrastructure: Analysis by scanning and transmission electron microscopy. Texas Rep. Biol. Med., 34: 1 (1976).

3. Boat, T. F., Kleinerman, J. I., Fanaroff, A. A., and Matthews, L. W.: Toxic effects of oxygen on cultured neonatal respiratory epithelium. Pediatr. Res., 7: 607 (1973).

4. Boat, T. F., Cheng, P. W., Iyer, R. N., Carlson, D. M., and Polony, I.: Human respiratory tract secretions. Arch. Biochem. Biophys., 177: 95 (1976).

5. Boat, T. F. and Cheng, P. W.: Mucous glycoproteins in cystic fibrosis. In: Ed., E. F. Walborg, Glycoproteins and Glycolipids in Disease Processes, ACS Symposium Series No. 80, pp. 108-121 (American Chemical Society, Washington, D.C., 1978).

6. Bogart, B. I., Conod, E. J., and Conover, J. H.: The biological activities of cystic fibrosis serum. 1. The effect of cystic fibrosis sera and calcium ionophore A23187 on rabbit tracheal explants. Pediatr. Res., 11: 131 (1977).

7. Bogart, B. I., Conod, E. J., Gaerian, E. F., and Conover, J. H.: The biologic activities of cystic fibrosis serum. II. Ultrastructural aspects of the effect of cystic fibrosis sera and calcium ionophore A23187 on rabbit tracheal explants. Pediatr. Res., 12: 15 (1978).

8. Bowman, B. H., Lockhart, L. H., and McCombs, M. L.: Oyster ciliary inhibition of cystic fibrosis factor. Science, 164: 325 (1969).

9. Bowman, B. H., Barnett, D. R., Carson, S. D., and McNeely, M. C.: Studies of cystic fibrosis utilizing mucociliary activity in oyster gills. Fed. Proc. 39: 3195 (1980).

Copyright $(\mathcal{C} 1982$ International Pediatric Research Foundation, Inc. $0031-3998 / 82 / 1609-0792 \$ 02.00 / 0$
10. Colton, T. E.: Statistics in Medicine, p. 131 (Little, Brown, and Co., Boston, Mass., 1974).

11. Conover, J. H. and Conod, E. J.: The influence of cystic fibrosis serum and calcium on secretion in rabbit tracheal mucociliary apparatus. Biochem. Biophys. Res. Commun., 83: 1595 (1978).

12. Czegledy-Nagy, E. and Sturgess, J. M.: Cystic fibrosis: Effects of serum factors on mucus secretion. Lab. Invest., 35: 588 (1976).

13. Doershuk, C. F., Matthews, L. W., Tucker, A. S., Nudelman, H., Eddy, T. G., Wise, M., and Spector, S.: A 5 year clinical evaluation of a therapeutic program for patients with cystic fibrosis. J. Pediatr. 65: 677 (1964).

14. Fleming, $N$. and Sturgess, J.: Cystic fibrosis serum stimulates giycoprotein secretion in dissociated acinar cells from rat submandibular glands. Cystic Fibrosis Club Abstracts, p. 40 (Cystic Fibrosis Foundation, Rockville, Md. 1979).

15. Gallagher, J. T. and Kent, P. W.: Structure and metabolism of glycoproteins and glycosaminoglycans secreted by organ cultures of rabbit trachea. Biochem. J., 148: 187 (1975).

16. Kurlandsky, L. E., Berninger, R. W., and Talamo, R. C.: A quantitative in vitro model for the study of mucus-producing substances in cystic fibrosis. Pediatr. Res., 14: 1263 (1980).

17. Lowry, O. H., Rosebrough, N. J., Farr, A. L., and Randall, R. J.: Protein measurement with the Folin phenol reagent. J. Biol Chem, 193: 265 (195I).

18. Osserman, E. F. and Lawlor, D. P.: Serum and urinary lysozyme (muramidase) in monocytic and monomyelocytic leukemia. J. Exp. Med., 124: 921 (1966).

19. Venipuncture of human subjects in this study was approved by the Human Experimentation Committee of University Hospitals of Cleveland and was performed with informed consent of all participants.

20. The authors wish to thank Dr. Robert C. Stern for assistance in the procurement of blood samples, Dr. Bernard Tandler for microscopic observations of rabbit tracheal epithelium, and Dr. James Sherman for helpful suggestions during manuscript preparation.

21. Requests for reprints should be addressed to: Thomas F. Boat, M.D., Department of Pediatrics, U. of North Carolina School of Medicine, Chapel Hill, North Carolina 27514.

22. This research was supported in part by NIH Grants AM 08305 and HL 26759 and by a grant from the Cystic Fibrosis Foundation, Rainbow Chapter.

23. Received for publication June 26, 1981 .

24. Accepted for publication March 10, 1982. 